\title{
ESTETIKA VISUAL IKLAN TELEVISI STUDI KASUS ("MOTHER'S DAY" DANCOW EXCELNUTRI+)
}

\author{
Dani Manesah \\ Program Studi Televisi dan Film Universitas Potensi Utama \\ manesahh@gmail.com
}

\begin{abstract}
ABSTRAK
Penelitian ini berjudul Estetika Visual Iklan Televisi Studi Kasus "Mother's Day" Dancaow Excelnutri+ di program televisi.Dalam penelitian ini peneliti menggunakan metode penelitian kualitatif dan menggunakan pendekatan estetika media terapan. Iklan Dancow Excelnutri+ menggambarkan susu yang diformulasikan untuk perkembangan anak yang berusia 1sampai 3 tahun dan merupakan sebuah pembaruan dari produk Nestlé Research Centre, dengan adanya kandungan $3 X$ Lactobacillus rhamnosus. Produk DANCOW Advanced Excelnutri+ juga mengandung lactobacillus rhamnosus, dengan adanya campuran lactobacillus rhamnosus akan mempunyai fungsi serat pangan inulin, tinggi vitamin A,C,E,D dan Zink, serta mengandung Omega 3 dan Omega 6. Adapun tujuan dalam penelitian ini adalah untuk mengetahui estetika media terapan yang terdapat dalam iklan Dancow Excelnutri+ dan ingin memberikan informasi kepada masyarakat terhadap keberadaan iklan Dancow Excelnutri+ tersebut. Hasil yang didapat dengan melakukan analisis berdasarkan konteks visualisasi iklan Dancow Excelnutri+ tersebut dibagi menjadi lima elemen yaitu adanya warna dan cahaya, ruang dua dimensi, ruang tiga dimensi, waktu/gerakan, dan suara, yang terdapat pada setiap scene baik dari scene 1 sampai dengan scene 8.
\end{abstract}

Kata Kunci : Iklan, Televisi, Dancaow, Estetika,

\begin{abstract}
This research is titled Visual Aesthetics of Television Advertising Case Study "Mother's Day" Dancaow Excelnutri + in television programs. In this study researchers used qualitative research methods and used an aesthetic approach to applied media. The Dancow Excelnutri + ad describes milk which is formulated for the development of children aged 1 to 3 years and is an update of the Nestle Research Center product, with $3 X$ Lactobacillus rhamnosus content. DANCOW Advanced Excelnutri + products also contain lactobacillus rhamnosus, with the mixture of lactobacillus rhamnosus having the function of inulin food fiber, high in vitamins A, C, E, D and zinc, as well as containing Omega 3 and Omega 6. The purpose of this study is to determine the aesthetics of the food fiber. applied media contained in the Dancow Excelnutri + ad and wants to provide information to the public regarding the existence of the Dancow Excelnutri + ad. The results obtained by analyzing the visualization context of the Dancow Excelnutri + ad are divided into five elements, namely the presence of color and light, two-dimensional space, three-dimensional space, time / motion, and sound, which are found in each scene from scene 1 to scene. 8
\end{abstract}

Keywords: Advertising, Television, Dancaow, Aesthetics. 


\section{PENDAHULUAN}

Televisi merupakan sebuah media yang sangat efektif dalam menyampaikan sebuah pesan dan juga beberapa fungsi, baik itu sebagai media promosi, pendidikan dan hiburan. Selain itu televisi juga sangat berperan dalam media iklan, karena televisi diklaim menjadi sebuah senjata yang ampuh dalam mempromosikan sebuah iklan dan mempunyai beberapa unggulan diantaranya adalah, televisi mempunyai tingkat jangkauan konsumen yang luas, televisi juga mempunyai dampak yang sangat kuat, karena mampu menjangkau indra penglihatan dan pendengaran manusia sehingga kesan realistis mengkombinasikan sebuah gerakan dan suara, kemudian televisi di Indonesia, diakui sebagai media yang sangat kuat pengaruhnya, sehingga konsumen lebih percaya pada produk yang diiklankan di televisi (Kasali: 2007). Kata televisi sendiri berasal dari kata Tele dan berasal dari Bahasa Yunani, yang mempunyai arti "Jarak", sedangkan Visi berasal dalam Bahasa Latin yang mempunyai arti "citra atau gambar". Sehingga kata televisi berarti sebuah sajian gambar beserta audio yang dapat didengar dari sebuah keberadaan tempat yang yang mempunyai jarak jauh (Sutisno: 1993). Melalui media televisi suara dan gambar dapat ditampilkan secara bersamaan, sehingga dengan adanya suara dan gambar tersebut dapat memberikan sebuah kesan yang sangat realistis, dibandingkan dengan media yang hanya mampu menampilkan sebuah audio, seperti radio dan menampilkan visual saja seperti majalah. Televisi sebagai media promosi sangat cocok digunakan sebagai media promosi melalui tayangannya, sehingga banyak perusahaan dapat mengiklankan produk-produk yang dihasilkan, dan menjual produk tersebut ketangah masyarakat.

Iklan televisi selalu berhubungan dengan suatu kegiatan pemasaran, dikarenakan iklan adalah salah satu sarana komunikasi yang sangat efektiv dalam memperkenalkan produk maupun merek sebuah perusahaan. Selain untuk membangun sebuah kesadaran merek (Brand Awarenes), iklan juga dugunakan untuk memberikan informasi tentang sebuah produk dan informasi lainnya, serta untuk membangun citra dan identitas. Karena keunggulan yang dimiliki oleh televisi, sehingga banyak perusahaan yang menggunakan televisi sebagai media utama untuk promosi. Salah satu produk yang yang menggunakan televisi sebagai media untuk mempromosikan produknya adalah produk Dancow. Nestlé DANCOW Excelnutri+ sebagai susu perkembangan untuk anak-anak yang terdapat di Indonesia DANCOW memahami bahwa pandangan penting dari pola aturan bimbingan orang tua mencakup nutrisi dan stimulasi. Hal tersebut berguna untuk melengkapi sebuah pandangan untuk nutrisi, pada kesempatan tersebut produk dari Nestlé DANCOW Excelnutri + mengeluarkan sebuah produk inovasi baru yaitu Nestlé DANCOW Excelnutrit, sebuah inovasi yang baru dari Nestlé Research Center, Swiss. Nestlé DANCOW Excelnutri+ hadir dengan dengan tiga keutamaan yang terdapat dari nutrisi tersebut berguna untuk perlindungan, perkembangan otak dan pertumbuhan fisik anak-anak (https://www.nestle.co.id) diakses pada tanggal 13 Desember 2018.

Guna mendukung orang tua agar anak-anak memperoleh hasil belajar dan bereksplorasi, Nestlé DANCOW Excelnutri+ memperkenalkan sebuah produk Ranch Adventure, yaitu sebuah tempat bermain yang membentuk pembiakan ternak termegah di Kota Jakarta dan dirancang guna memberikan rancangan untuk seluruh panca indera manusia seperti melihat, mendengar, menyentuh, mencium dan merasakan. Hal tersebut dibentuk untuk menunjang kecakapan terhadap saraf sensorik dan motorik, kecakapan dalam hubungan komunikasi, dan bentuk sosial-emosional, kemandirian, perkembangan kognitif dan kreativitas si anak .Ranch Adventure memperlihatkan 7 (tujuh) kegiatan yang terdapat pada animal petting, fishing area, cow milking serta pony riding yang mengarahkan anak untuk lebih berani dalam interaksi serta bersimpati kepada hewan. 
Terdapat pula kegiatan puzzle dan hay maze yang akan membuat memori dan keberanian si anak untuk menyiapkan masalah dan juga membangun kekompakan serta hubungan antara ibu dan anak. Tidak hanya terdapat pula sebuah kegiatan berkebun yang bertujuan untuk mengarahkan anak untuk lebih mengetahui bahkan mencintai tumbuhan. Ranch Adventure juga menyediakan tempat untuk berkonsultasi agar ibu dapat berkonsultasi langsung mengenai tumbuh dan kembang si anak dengan ahlinya."Cinta ibu dengan memberikan nutrisi dan stimulasi yang baik dapat mengoptimalkan masa depan si Kecil. Mari berikan perlindungan terbaik untuk si Kecil guna mendukung eksplorasinya. Kami berharap kegiatan bersama keluarga di Ranch Adventure ini dapat memperkuat momen orang tua bersama si Kecil sehingga menjadikan si Kecil tangguh dan kreatif," (https://www.nestle.co.id) diakses pada tanggal 13 Desember 2018.

\subsection{Iklan.}

Setiap iklan dipersiapkan untuk tujuan yang berbeda sesuai dengan kebutuhan, baik yang berkaitan dengan produk maupun institusi tertentu. Pengiklan menggunakan pesan iklan untuk mencapai tiga tujuan utama, yaitu untuk menginformasikan, membujuk, dan mengingatkan. Secara umum, iklan terbagi menjadi dua kategori, yaitu (1) iklan kelembagaan (Institutional advertising), adalah iklan yang mempromosikan konsep, ide, filosofi, atau niat baik suatu industri, perusahaan, organisasi, orang, lokasi geografis, atau instansi pemerintah (Kurtz, 2008: 527). Jenis iklan ini tidak hanya memiliki manfaat sosial, tetapi juga membantu untuk membangun citra organisasi; dan (2) iklan produk (product advertising) adalah iklan yang berisi penjualan nonpersonal dari barang atau jasa tertentu, merupakan jenis iklan yang paling sering digunakan dalam kegiatan promosi (Pride dan Ferrell, 2009: 423).

Menurut Kotler (2006), iklan diartikan sebagai segala bentuk penyajian non-personal tentang ide, barang, atau jasa oleh suatu sponsor tertentu yang memerlukan pembiayaan. Sedangkan menurut Kurtz (2008: 527), Iklan adalah komunikasi nonpersonal berbayar melalui berbagai media tentang sebuah perusahaan bisnis, organisasi nirlaba, produk, atau ide oleh sponsor diidentifikasi dalam pesan yang dimaksudkan untuk menginformasikan, membujuk, atau mengingatkan anggota audiens tertentu. Jadi iklan merupakan bentuk komunikasi yang bersifat non personal atau massal dari pihak pengiklan, membutuhkan biaya tertentu dan media tertentu yang tujuanya untuk menyampaikan pesan pada audience tertentu.

Menurut Pride dan Ferrell (2009: 423), berdasarkan tujuanya iklan produk terdiri dari empat macam, yaitu (1) Iklan perintis (pioneer advertising), tujuanya untuk merangsang permintaan produk (bukan merek tertentu) dengan menginformasikan pelanggan potensial tentang fitur, kegunaan, dan manfaat produk, jenis iklan ini digunakan bila produk berada dalam tahap perkenalan produk; (2) iklan kompetitif (competitive advertising) atau iklan persuasif, tujuannya untuk mendorong permintaan terhadap merek tertentu dengan mempromosikan fitur merek, penggunaan, keuntungan, dan untuk membuat perbandingan produk secara langsung maupun tidak langsung; (3) iklan pengingat (reminder advertising), iklan pengingat tujuannya untuk memberitahu pelanggan tentang keberadaan merek tertentu yang masih di sekitar dan masih menawarkan karakteristik, penggunaan, dan keuntungan tertentu; (4) iklan penguatan (reinforcement advertising), tujuanya untuk menjamin pengguna saat ini, bahwa mereka telah memilih merek yang tepat dan memberitahu mereka bagaimana mendapatkan kepuasan maksimal dari merek tersebut. 


\section{STUDI LITERATUR} berikut.

Beberapa referensi penulisan dirujuk oleh peneliti dalam tulisan ini adalah sebagai

1. Ezekle,Leo, dan Comfort. "Pemanfaatan Estetika Pada Iklan Televisi". Mengkaji pemanfaatan estetika pada iklan. Tujuan dalam penelitian ini adalah bahwa iklan televisi memerlukan elemen estetika untuk menarik pemirsa. Penelitian ini merekomendasikan antara lain bahwa pengiklan harus berusaha membuat penonoton memiliki pengalaman estetik dalam produk dan layanan terus menerus diiklankan sehingga membuat konsumen menjadi setia kepada produk tersebut.

2. Jurnal Desain Komunikasi Visual \& Multimedia 2.02Sulaiman, Annas Marzuki. "Kajian Bentuk Visual Iklan (Studi Kasus Iklan Oreo Versi Bayangkan Kuberi Oreo Saat Ramadhan)." Andharupa: (2016): 137-150. Tujuan dari penelitian ini adalah untuk mengetahui dan menganalisis bentuk visual dalam iklan Oreo versi "Bayangkan Kuberi Oreo Saat Ramadhan" di televisi dengan menggunakan pendekatan Estetika Media Terapan. Dari analisis yang telah dilakukan berdasarkan kontekstual visual iklan yang membagi elemen gambar menjadi lima elemen yaitu: cahaya dan warna, ruang dua-dimensi, ruang tiga-dimensi, waktu/gerakan, dan suara.

3. HUMANIORA VOL.5 NO.2 Oktober 2017 "Analisis Iklan Televisi Di Indonesia" dalam jurnal ini membahas tentang iklan yang tayang pada hari sabtu mingu dengan menggunakan metode kuantitatif, dan metode kuantitatif yang digunakan adalah metode analisis konten. Hadil dalam penelitian ini adalah 37 dari 120 jam program televisi adalah iklan dengan 6898 iklan promosi maupun produk.

4. Decky Avrilukito Ismandoyo Disertasi "Estetika Iklan Televisi Axe Versi "Kencan dengan Bidadari". Penelitian yang dilakukan oleh Decky Avrilukito Ismandoyo bertujuan untuk menjelaskan dan memaparkan struktur estetika dari sebuah iklan. Dalam hal ini penelitian difokuskan pada iklan televisi Axe Indonesia Versi Kencan Dengan Bidadari. Hasil penelitian menunjukkan bahwa iklan Axe Indonesia versi Kencan Dengan Bidadari telah memenuhi kaidah estetika pada iklan mdium televisi. Hasil tersebut diharapkan dapat menjadi landasan penelitian berikutnya untuk melengkapi kebutuhna pada estetika iklan pada medium serupa maupun lainnya.

\section{PEMBAHASAN}

Untuk mengkaji bentuk sebuah iklan televisi Dancow Excelnutri+ peneliti menggunakan metode analisis Estetika Media Terapan (Applied Media Aestetic) yang dikemukakan oleh Herbert Zettl. Teori Estetika Media Terapan merupakan sebuah kajian bentuk iklan yang ditujukan khusus untuk media televisi dan film bagaimana menjelaskan elemen-elemen desai dapat terstruktur dan diterapkan dalam menghasilkan gambar visual dan suara secara maksimal dan efektif didalam video dan didalam sebuah film. Secara kontekstual Teori Estetika Media Terapan ini membagi elemen-elemen gambar dari video dan film terdiri dari: (1) cahaya dan warna, (2) ruang dua-dimensi, (3) ruang tiga dimensi, (4) waktu/gerakan (ruang empat dimensi), dan (5) suara.

Sebelum peneliti melakukan analaisis pada iklan Dancow, peneliti melakukan pemilihan terhadap scene yang dianggap mewakili pada keseluruhan iklan. Scenescene tersebut kemudian diidentifikasi untuk mengetahui bentuk iklan melalui elemenelemen visual pembentuk iklan. Berikut ini adalah hasil analisis pada iklan program televisi Dancow Excelnutri+ menggunakan metode analisis Estetika Media Terapan (Applied Media Aestetic) yang dikembangkan oleh Herbert Zettl, dan dapat dilihat pada gambar dibawah ini. 


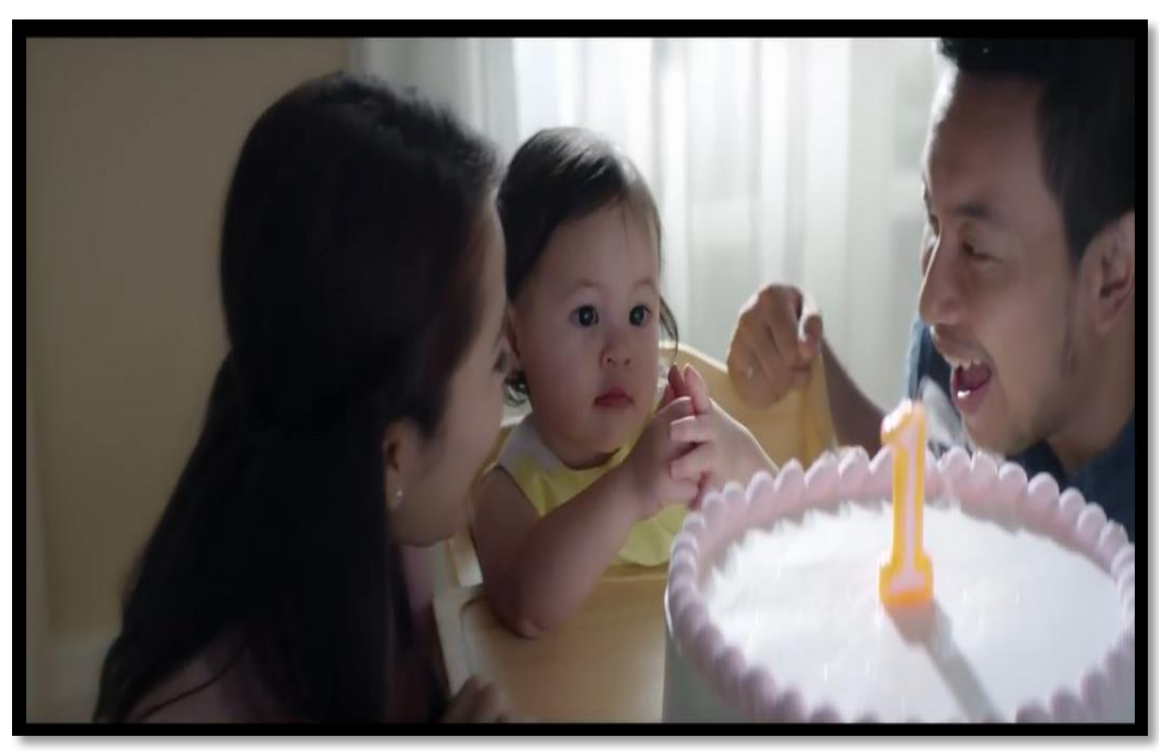

\section{Gambar 1. Sebuah keluarga yang sedang merayakan ulang tahun Sumber : http://youtube.com}

\section{Scene 1}

Sebuah keluarag kecil yang sedang merayakan pesta ulang tahun anaknya, yang terdiri dari seorang laki-laki muda yang memakai baju berwarna biru dongker dan seorang perempuan yang memakai baju berwarna crem sedang bercengkrama menghadap ke wajah anak perempuan karena telah meniup lilin ulang tahun angka 1 dan berwarna kuning, dan sama dengan pakaian yang kenakan oleh anak tersebut. Sementara cahaya dan warna Pencahayaan datar didominasi oleh warna cenderung redup, namun terdapat pembiasan cahaya yang mengenai sebuah gorden jendela dan lilin, sehingga menimbulkan bayangan hitam diatas bolu tersebut, nuansa lingkungan cenderung redup dikarenakan dinding yang terdapat dibelakang tubuh sang anak, berwarna crem. Ruang dua- dimensi aspek rasio layar 1,78: 1, teknik pengambilan gambar menggunakan Close Up, yang menampilkan gambar sangat jelas pada sosok laki-laki, perempuan dan anak perempuan yang sedang duduk menggunakan baju berwarna kuning. Posisi kamera sedikit lebih tinggi dari objek keluarga tersebut namun, keseimbangan dalam foto tersebut menggunakan keseimbangan yang dinamis.Ruang tigadimensi Dalam ruang tiga dimensi, terdapat objek yang menutupi objek, dan ketajaman focus pengambilan gambar menunjukkan kedalaman, pada adegan ini terlihat posisi kue ulang tahun berada di depan, sementara sosok laki-laki yang mengenakan baju berwarna biru dongker terlihat diesebelah kanan, dan perempuan yang mengenakan baju berwarna crem berada disebelah kiri, dan sang anak berada ditengah. Dengan background dinding yang berwarna $\mathrm{crem}$ serta kain gorden yang berwarna putih. Waktu/ Gerakan: 6 detik/ seorang laki-laki dan perempuan serentak bergerak melihat wajah sang anak. Suara: Instrumental Piano. 


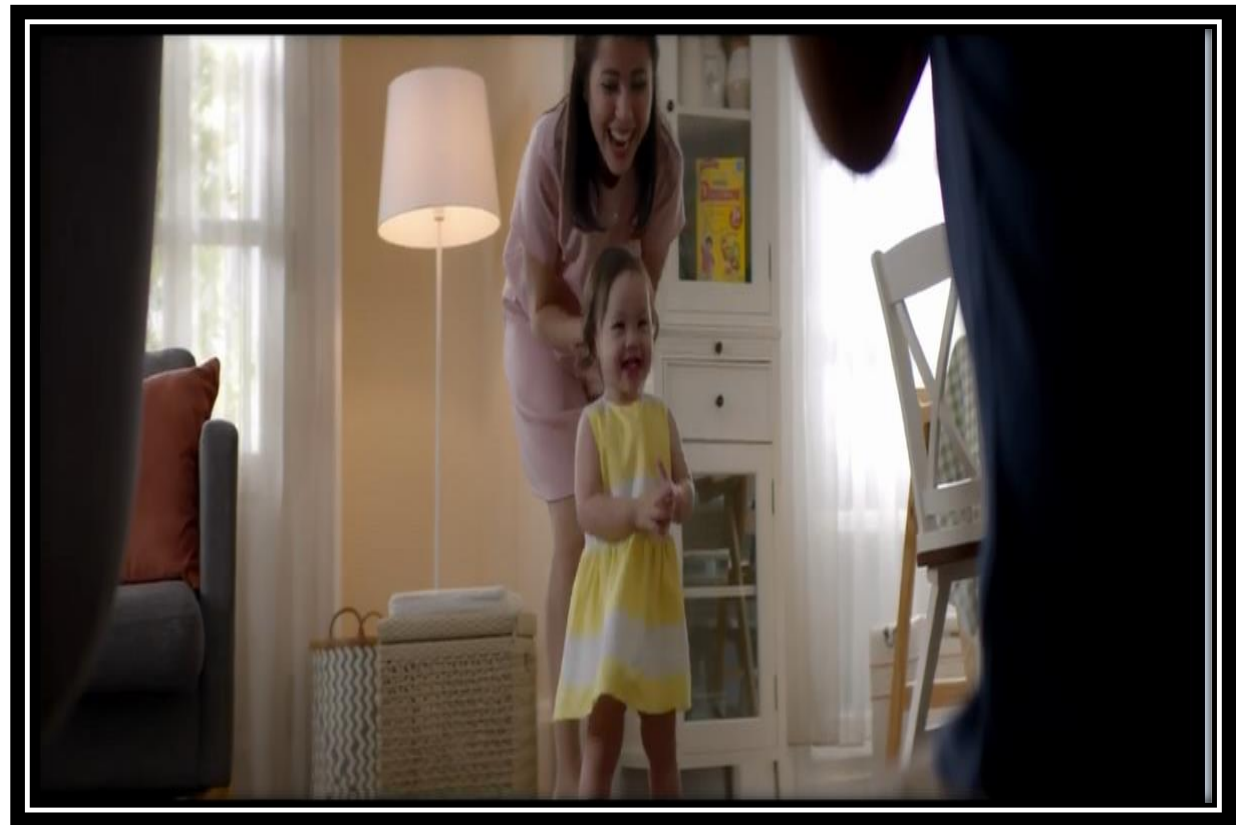

Gambar 2. Seorang anak yang sedang belajar berjalan Sumber : http://youtube.com

\section{Scene 2}

Pada adegan ini seorang perempuan sedang membungkuk dan seorang anak yang sedang berdiri, dan seorang laki-laki sedang mengambil foto anaknya. Cahaya dan Warna. Pencahayaan yang terdapat dalam adegan tersebut didominasi oleh cahaya hangat yang dihasilkan oleh lampu yang berada di ruang tamu, dan adanya cahaya alami yang mengenai gorden tersebut. Background didominasi oleh warna putih, yang berasal dari warna lemari, gorden jendela dan meja makan. Ruang dua-dimensi. Teknik pengambilan gambar yang dilakukan dalam adegan ini adalah Wide shot yang menampilkan area lebih luas dan susu Dancow berada di atas lemari yang berwarna putih. Ruang tiga-dimensi. Dalam pengambilan gambar ini adegan lebih menekankan perbedaan dimana objek perempuan yang sedang jongkok dan menepuk tangan dan seorang anak yang berada ditengah-tengah orang tuanya dan tersenyum.Waktu/ Gerakan. 13 detik/ anak perempuan yang sedang merayakan ulang tahun berdiri menuju ayahnya yang sedang mengambil foto. Suara. Instrumental Piano, suara anak tertawa, dan suara tepukan tangan.

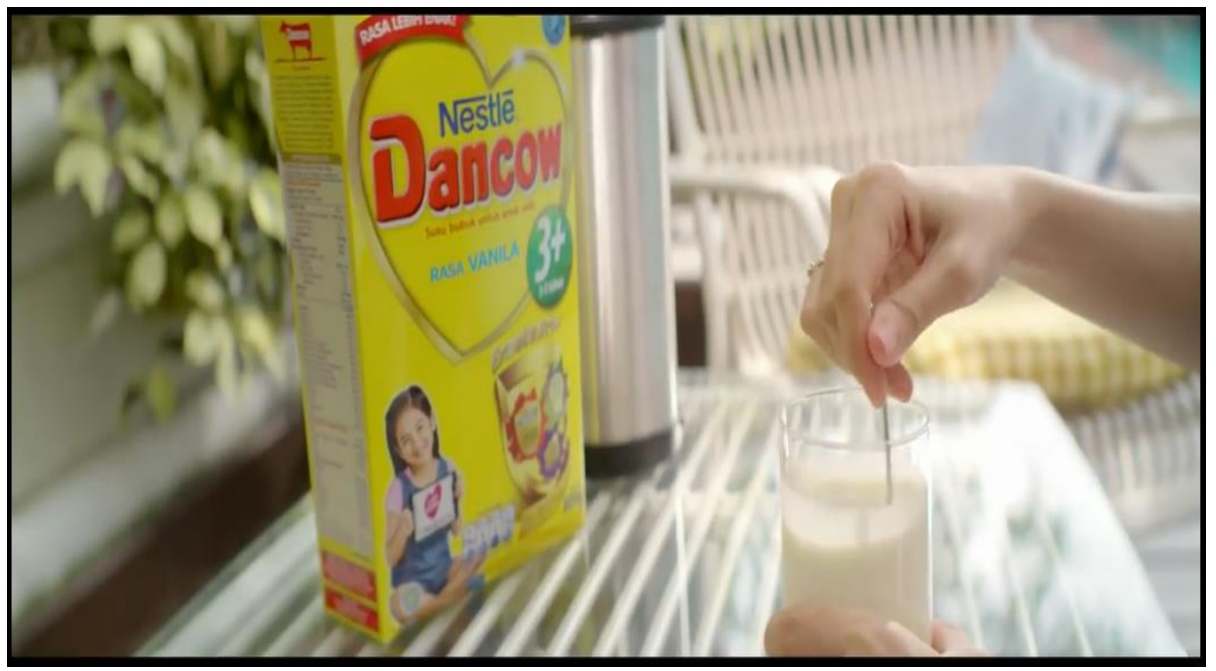

Gambar 3. Produk susu Dancow yang berada di atas meja. Sumber: $\underline{\text { http://youtube.com }}$ 


\section{Scene 3}

Pada adegan ini susu Dancow berada diatas meja kaca. Cahaya dan Warna: Pencahayaan datar, warna didominasi oleh warna produk nestle Dancow yaitu berwarna kuning, ditambah dengan cahaya alami yang dihasilkan dari matahari, dan cahaya matahari terlihat memantul mengenai meja kaca yang berwarna bening, sedangkan produk susu Dancow terlihat lebih menonjol, dengan latar belakang dedaunan yang berwarna hijau. Ruang dua-dimensi: Teknik pengambilan gambar yang terdapat dalam gambar diatas menggunakan big close up, sehingga objek terlihat sangat jelas pada tulisan Dancow, posisi kamera statis yaitu komposisi yang memperlihatkan objek ditengah bidang sehingga objek yang ditangka menimbulkan kesan elegan. Ruang tiga-dimensi: Dalam pengambilan gambar ini, kamera lebih fokus dan tajam mengarah ke susu Dancow, yang berada diatas meja kaca, sementara posisi tangan yang sedang memgang gelas berada didepan susu tersebut. Waktu/ Gerakan: 22 detik/ anak perempuan yang berusia lima tahun, sedang mengaduk segelas susu Dancow yang siap untuk diminum, dan posisi tangan memgang gelas dan sendok untuk mengaduk susu tersebut. Suara: Instrumental Piano, suara adukan gelas, dan suara air yang mengalir.

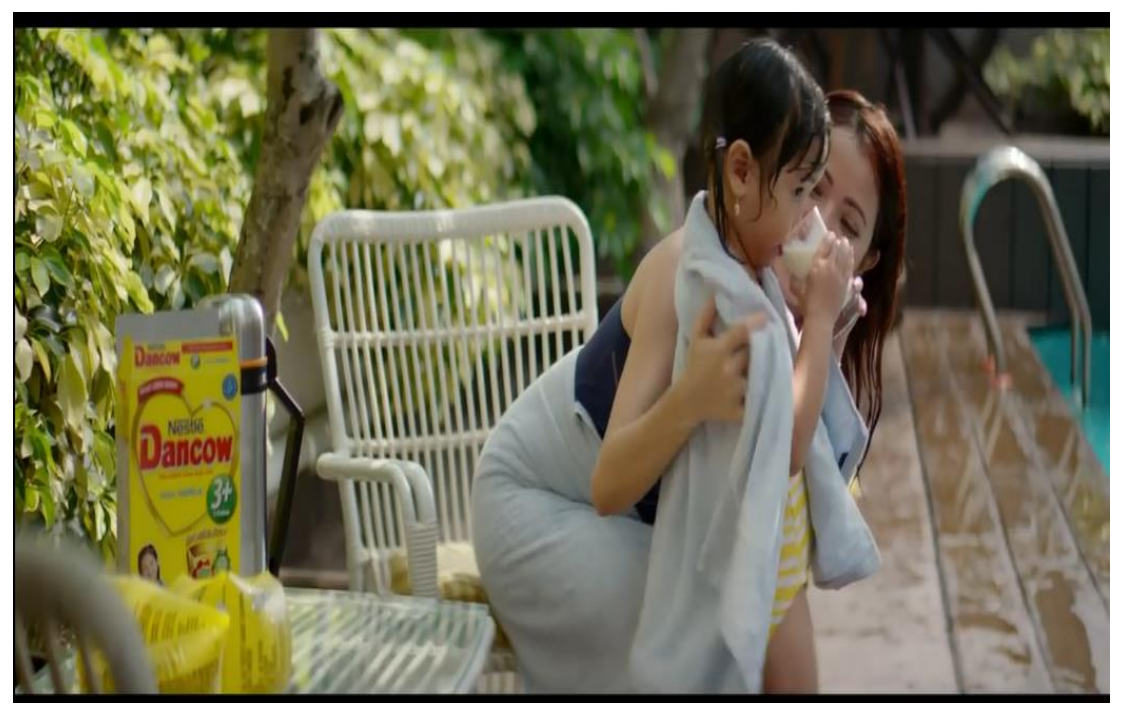

\section{Gambar 4. Seorang ibu yang sedang mengeringkan badan anaknya Sumber: http://youtube.com}

\section{Scene 4}

Pada adegan ini terlihat ibu dan anaknya yang sedang duduk dibangku taman didekat kolam renang, sang ibu terlihat sedikit menunduk dan memegang handuk berwarna putih, dan sang ibu mengenakan baju kaos yang berwarna hitam, sementara sang anaka mengekana baju renang yang berwarna kuning senada dengan produk dancow yang berada diatas meja. Handuk yang dipegang oleh ibu sang anak digunakan untuk mengeringkan anaknya yang telah selesai berenang. Cahaya dan Warna: Pencahayaan datar, cahaya didominasi oleh cahaya alami yang dihasilkan oleh matahari, cahaya tersebut mengenai pepohonan yang terdapat dibelakang bangku, latar belakang didominasi oleh warna hijau, yang dihasilkan oleh pohon yang berada disekitar kolam renang, warna hijau yang dihasilkan memberikan kesan sejuk bagi yang melihatnya. Ruang dua-dimensi: Teknik pengambilan gambar yang digunakan dalam gambar diatas menggunakan medium close up, pengambilan gambar diatas memperlihatkan dua orang manusia yang berada dalam satu frame, dan sebuah produk susu dancow yang berada diatas meja kaca. Ruang tiga-dimensi: Manipulasi kedalaman perspektif dengan memanfaatkan kedudukan objek dan selektif focus, yaitu fokus terlihat pada sang ibu yang sedang mengeringkan badan sang anaka yang telag selesai berenang, dan membawa produk susu dancow ke kolam renang tersebut. Waktu/ Gerakan: 26 detik/ gerakan ibu yang sedang mengeringkan badan sang anak, samabil tersenyum sementara sianak juga terlihat tersenyum sambil memegang segelas susu yang ada ditangannya. Suara: Instrumental Piano Jingle susu Dancaow, suara air yang mengalir. 


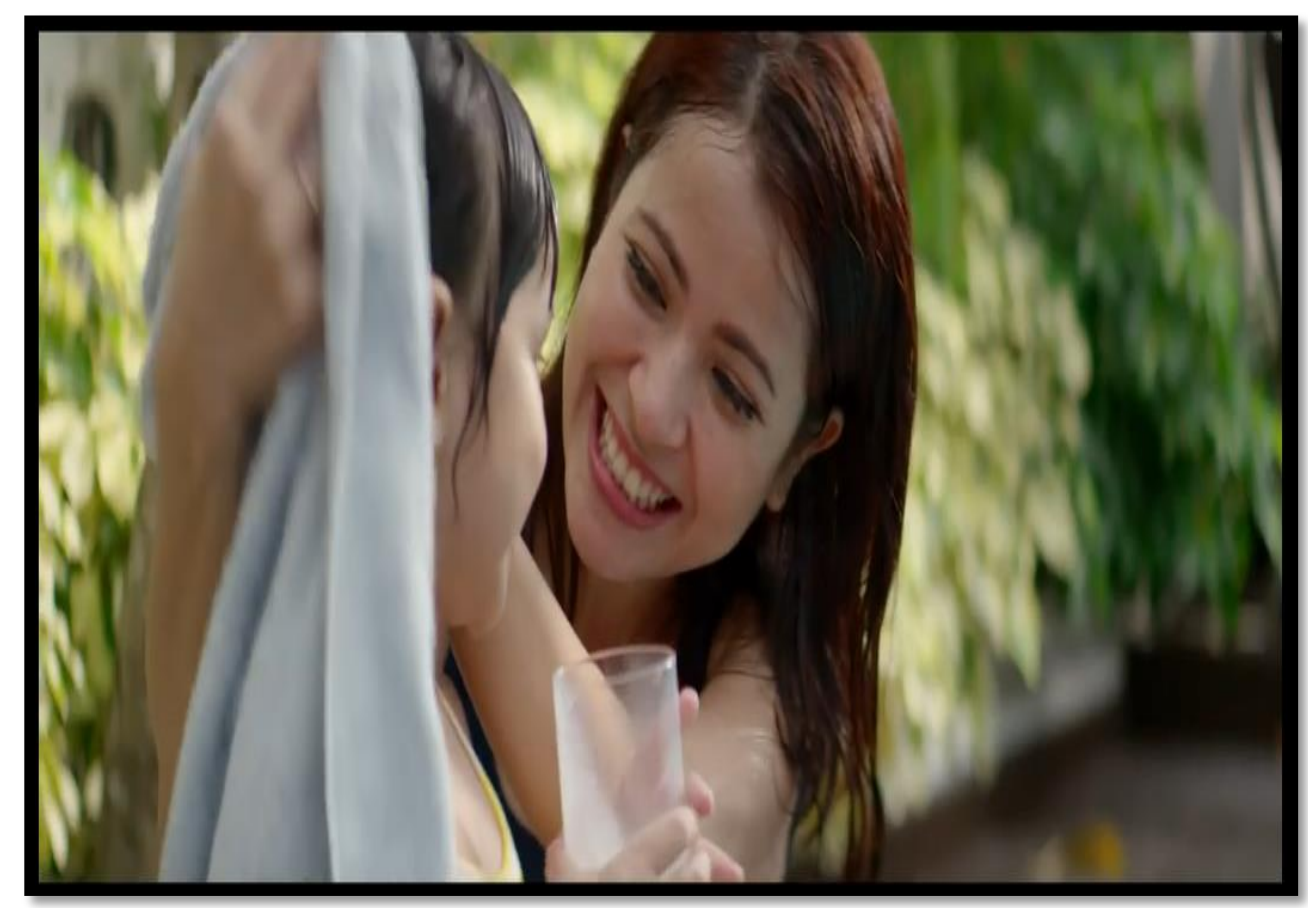

Gambar 5. Seorang ibu yang sedang mengeringkan rambut anaknya Sumber: http://youtube.com

\section{Scene 5}

Ekspresi seorang ibu yang melihat anaknya tumbuh besar, yang memandang anaknya dengan penuh senyuman secara dekat, dengan ekspresi yang penuh harap. Cahaya dan Warna: Pencahayaan datar, nuansa lingkungan berwarna sejuk dan hangat, sejuk dihasilkan oleh tumbuhan yang ada disekitar kolam renang, sementara warna yang hangat dihasilkan oleh cahaya matahari. Ruang dua-dimensi: Teknik pengambilan gambar yang digunakan dalam gambar diatas menggunakan teknik close up yang memperlihatkan wajah sang ibu sangat jelas. Ruang tiga-dimensi: Manipulasi kedalaman perspektif dengan memanfaatkan selektif focus, yaitu fokus terlihat pada area sumbu Z (wajah) sang ibu terlihat jelas dan dekat, teknik close up yang dilakukan dalam adegan ini agar objek terlihat jelas.Waktu/ Gerakan: 26 detik/ gerakan ibu yang sedang mengeringkan badan sang anak, sementara tangan sang ibu yang memegang handuk, tampak sedang mengeringkan rambut sang anak. Suara: Instrumental Piano Jingle susu Dancaow, suara air yang mengalir. 


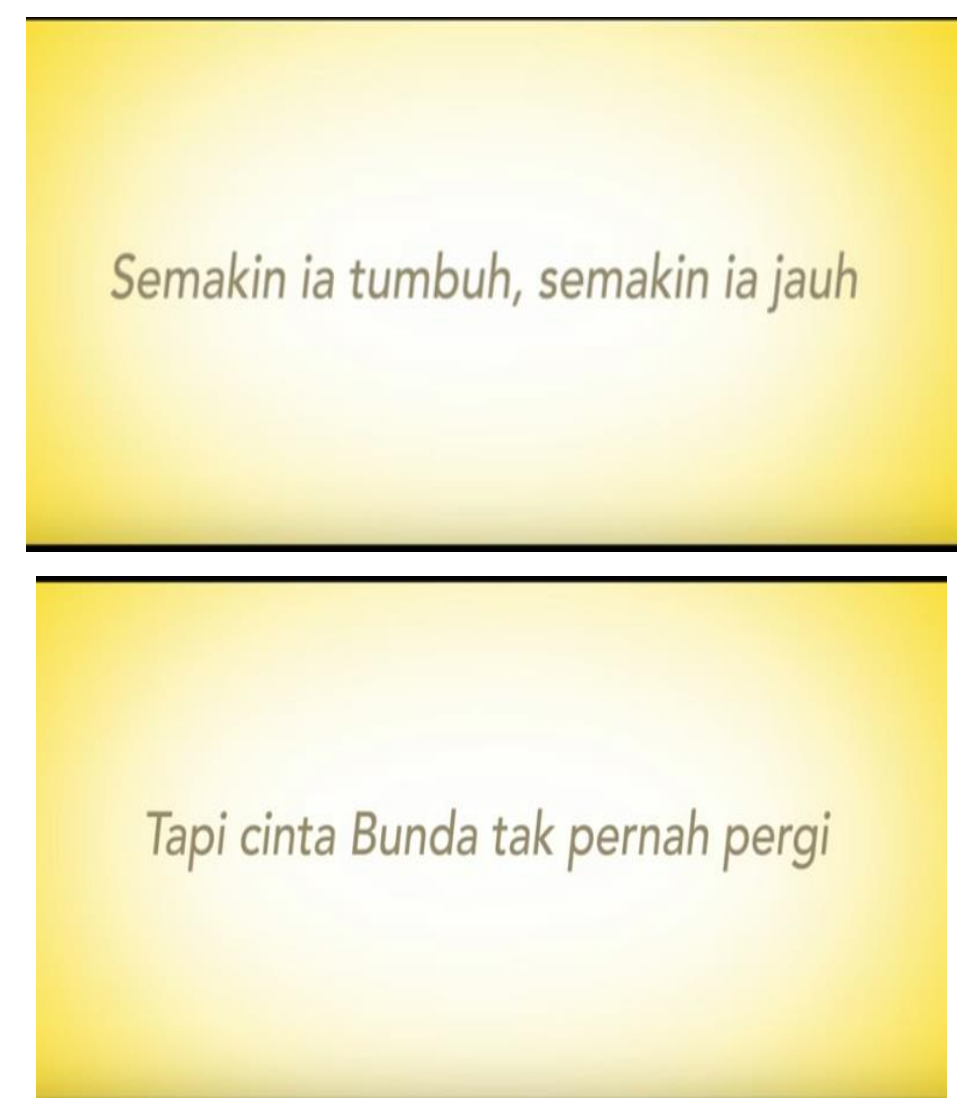

Gambar 6. Sebuah gambar yang bertuliskan Semakin ia tumbuh, semakin ia jauh. Tapi cinta Bunda tak pernah pergi

Sumber: http://youtube.com

\section{Scene 6}

Terdapat sebuah ilustrasi gambar dengan tulisan semakin ia tumbuh semakin ia jauh. Tapi Cinta Bunda Tak Pernah Pergi. Cahaya dan Warna:Produk Dancow berwarna kuning, dan terdapat warna putih didalamnya, yang menunjukkan cahaya yang kilau. Sementara background berwarna kuning. Ruang dua-dimensi: Obyek sebuah tulisan yang berada ditengah-tengah dan membentuk sebuah keseimbangan yang terpusat. Ruang tiga-dimensi: Tidak terdapat kebuah kedalaman. Waktu/ Gerakan: 1 menit 33 detik, objek dan kamera yang diam. Suara:Instrumental Piano Jingle susu dancow yang perlahan-lahan diam.

\section{Analisis Estetika Media Terapan (Applied Media Aestetic)}

\section{a. Elemen 1, Cahaya dan Warna:}

\section{Cahaya dan Bayangan}

Pencahayaan yang terdapat pada seluruh iklan ini memiliki teknik yang berbeda, pencahyaan yang terdapat pada para aktor Dancow Excelnutri+ menggunakan cahaya yang datar, dan menggunakan cahaya yang terlihat datang dari segala arah sehingga bayangan yang terlihat pada aktor terlihat tipis dan hampri tidak ada. Pencahayaan datar mengungkapkan sumber cahaya tertentu kecuali untuk backlight yang kuat. Jenis cahaya Backlight terlihat sangat jelas pada gambar diatas, yaitu terlihat pada jatuhnya cahaya dan mengenai lilin ulang tahun yang berwarna kuning dan dipadukan dengan warna putih yang berasal dari bolu ulang tahun tersebut sehingga menghasilkan nilai estetika yang indah. 


\section{Warna}

Warna dapat menunjukkan suasana, selain menunjukkan suasana warna juga berfungsi untuk menonjolkan satu obyek lebih menonjal dibandingkan dengan obyek lainnya. Dalam iklan dancow ini didominasi warna bahagia seperti kuning, dan perpaduan warna yang dipakai oleh aktor dalam iklan dancow tersebut. Kemasan dancow berwarna kuning yang dipadukan warna merah terlihat kontras diantara warna-warna hangat yang mendominasi disekitarnya. Warna kuning memberi arti kehangatan dan rasa bahagia dan seolah ingin menimbulkan hasrat untuk bermain. Dengan kata lain warna ini juga mengandung makna optimis, semangat dan ceria. Warna hangat dalam iklan Dancow ini didominasi oleh warna kuning dan warna merah muda (misalkan warna yang dipakai oleh aktor dan background didominasi juga warna kuning. Pada pertengahan iklan Dancow ini terlihat kegembiraan sebuah keluarga yang sedang merayakan ulang tahun anaknya. Kegembiraan tersebut dapat dilihat pada adegan 7 .

\section{b. Elemen 2, Bidang Dua Dimensi:}

\section{Area}

Aspek rasio layar digunakan dalam iklan dancow ini adalah aspek layar HDTV dengan ukuran $16 \times$ 9, atau 1,78: 1, membuat layar ini lebih membentang horizontal dari layar televisi tradisional. Aspek rasio HDTV dapat menampung format film layar lebar tanpa kehilangan gambar yang jatuh disisi kanan dan kiri. Teknik pengambilan gambar banyak menggunakan Close Up, Medium Close Up, serta Big Close Up. Teknik pengambilan gambar Close Up ini muncul pada Scene 1 dan 5, Medium Close Up terdapat pada scene 4, sedangkan teknik pengambilan gambar yang menggunakan Big Close Up terdapat pada Scene 3. Aspek layar HDTV cocok untuk menunjukkan area yang lebih luas secara horizontal sehingga akan menampilkan lebih banyak obyek dalam 1 scene yang menunjukkan kehangatan dan kebahagiaan yang terdapat pada scene 1, 2, dan 7. Dan lebih mudah juga untuk menunjukkan orang-orang yang sedang duduk ataupun dalam percakapan yang terlihat pada scene 4, dan 5.

\section{Kekuatan Dalam Layar.}

Dalam setiap scene yang terdapat pada iklan memiliki keseimbangan serta kekuatan massa grafis dan daya tarik dari bingkai layar. Berat yang terdapat pada gambar ditentukan oleh dengan dimensi objek serta berapa banyak daerah objek relatif terhadap total layar area. Dalam menonjolkan produk yang ditawarkan dalam iklan ini terdapat beberapa scene yang menampilkan Dancow pada posisi tengah namun agak ke bawah layar sehingga terlihat keseimbangan dinamis yang terdapat pada scene 2, 3, dan 4 .

\section{c. Elemen 3, Bidang Tiga Dimensi: Kedalaman dan Volume:}

Kedalaman bidang tiga dimensi dalam iklan ini dapat terlihat dengan adanya perbedaan ukuran ataupun volume secara kontras yang terdapat pada scene 2, dan 4 . Dimana obyek yang terletak dekat dengan kamera mempunyai ukuran yang lebih besar sedangkan obyek serupa yang diposisikan sebagai lebih jauh terdapat pada scene 2. Pembentukan kedalaman bidang ruang tiga dimensi terlihat pada scene 2 yaitu gerakan sang anak yang menggunakan pakaian yang berwarna merah muda berjelan kedepan dan menuju arah kamera. 


\section{d. Elemen 4, Waktu/Gerakan \\ 1. Waktu.}

Iklan Dancow Excelnutri+ ini berdurasi 1 menit 30 detik, dan masing-masing scene memiliki durasi yang berbeda-beda. Durasi yang panjang terdapat pada scene 2, dimana seorang anak perempuan yang sedang berjalan menuju sang ayah, sementara sang ibu terlihat sedang memegang anak tersebut dan melepasnya secara perlahan.

\section{Gerakan}

Gerakan yang terdapat dapat pada keseluruhan iklan Dancow Excelnutri+ ini terdiri dari gerakan kamera dan gerakan obyek. Dan keseluruhan gerakan tersebut menunjukkan gerakan yang normal, sehingga sebagian besar menunjukkan arah ke kanan dan ke depan. Dengan latar belakang yang berwarna kuning dan ditambah dengan efek warna yang bewarna putih muncul ilustrasi produk Dancow Excelnutri+ yang terdapat kalimat semakin ia tumbuh semakin ia jauh, tapi cinta bunda tak pernah pergi, kalimat tersebut dapat terlihat pada scene 6.

e. Elemen 5, Suara:

Semua scene yang terdapat dalam iklan ini diisi dengan suara piano. Dan terdapat pada scene terakhir terdapat narasi suara seoarng ibu yang berbunyi "tapi cinta bunda tak pernah pergi".

\section{PENUTUP}

Berdasarkan hasil pada pembahasan yang merupakan analisis dari Estetika Media Terapan (Applied Media Aestetic) terhadap iklan televisi Dancow Excelnutri+, dapat disimpulkan bahwa iklan Dancow Excelnutri+ berusaha menunjukkan keberadaan produk Dancow Excelnutri+ pada saat hari Ibu, dimana dalam setiap adegan pada iklan Dancow Excelnutri+ terdapat sosok Ibu yang sangat menyayangi anaknya, dari kecil hingga anak tersebut menikah dan mempunyai seorang anak, sosok Ibu selalu hadir didalam setiap adegan. Produk Dancow Excelnutri+ ditampilkan secara menonjol dengan memberikan sebuah pengaturan dan posisi, fokus dalam setiap ukuran dan setiap adegan yang ditampilkan sehingga menarik perhatian audiens. Produk Dancow Excelnutri+ juga ditampilkan dengan warna-warna yang kontras. Dancow Excelnutri+ yang berwarna kuning dipadukan dengan beberapa warna yang dihasilkan melalui cahaya alami seperti matahari, dan warna-warna hangat, warna dominan merah dan biru terlihat lebih menonjol dikarenaka latar belakang pada produk Dancow Excelnutri+ berwarna kuning. Adapun hasil yang didapat setelah peneliti menganalisis iklan televisi Dancow Excelnutri+ menggunakan teori estetika media terapan yaitu, adanya warna dan cahaya, ruang dua-dimensi, ruang tiga dimensi, waktu/gerakan dan suara pada setiap scene.

\section{DAFTAR PUSTAKA}

[1] Kasali, Rhenald. (2007). Manajemen Periklanan, Konsep dan Aplikasinya di Indonesia.Jakarta: Pustaka Utama Grafiti.

[2] Kurtz, David L. (2008). Contemporary Marketing. Mason: South-Western.

[3] Pride, William M. dan Ferrell, O. C. (2009). Foundations Of Marketing. Boston: Houghton Mifflin Company.

[4] Sulaiman, A. M., \& Murtana, I. N. (2016). Strategi Visual Iklan Televisi Kuku Bima Energi Produksi Pt. Sido Muncul Semarang. 
[5] Sutisno P.C.S.1993 Pedoman Praktis Penulisan Skenario Televisi dan Video. Jakarta: PT. Grasindo.

[6] Sutopo, H.B. 2006. Metodologi penelitian kualitatif: dasar teori dan terapannya dalam penelitian. Surakarta: Sebelas Maret University Press.

[7] Zettl, Herbert. 2014. Sight Sound Motion: Applied Media Aesthetics, Boston: Cengage Learning.

[8] Excelnutrit, Inovasi Terbaru Nestlé DANCOW 1+. [Online]. Tersedia: https://www.nestle.co.id/ina/media/press-releases/inovasi-terbaru-dancowexcelnutri-plus 13 Desember 2018

[9] DANCOW Advanced Excelnutrit 1+. [Online]. Tersedia: https://www.dancow.co.id/dpc/produk 13 Desember 2018

Webtografi.

[10] http://youtube.com 